\title{
THE INFLUENCE OF DISCOVERY LEARNING AND SNOWBALL THROWING METHOD IN IMPROVING WRITING SKILLS OF HIGH SCHOOL STUDENTS
}

\author{
Winda Intan Lestari ${ }^{1}$, Ulfah Mawaddah ${ }^{2}$, Evie Kareviati ${ }^{3}$ \\ ${ }^{1}$ IKIP Siliwangi \\ ${ }^{2}$ IKIP Siliwangi \\ ${ }^{3}$ IKIP Siliwangi \\ ${ }^{1}$ windastella25@gmail.com, ${ }^{2}$ ulfahmawaddah0505@gmail.com, ${ }^{3}$ akhmadjaelani91@yahoo.co.id
}

\begin{abstract}
The purpose of this study is to analyze the improvement of students' writing skills by using Discovery learning and the Snowball Throwing method. this study uses Quasi-Experimental by comparing two different variables with the stages of giving pre-test, treatment, and post-test and looking for the difference in value using the Gain Test. This research was conducted in class XI of SMK 4 Padalarang LPPM with a sample population of 60 students namely 30 students of class XI RPL 1 as control class and 30 students with discovery learning method and RPL 2 class as Experimental class with Snowball Throwing approach. From the results of this study conclusions are obtained 1). The ability to write students using the Snowball method is effective and better than using discovery learning. 2). There is a change in the value of writing narrative texts of students using the snowball method rather than discovery learning.
\end{abstract}

Keywords: Discovery Learning, Snowball Throwing Method, Writing Skills and Quasi-Experimental

\section{INTRODUCTION}

In learning English there are 4 skills that must be able mastered by students, namely listening, speaking, writing and reading. English, in Indonesia as a foreign language. Therefore, English becomes a difficult study to learn, one of which is writing. Usually, many people refuse to write in English because they feel it is hard and causes them to spell letter by letter from each type. Other causes are the lack of vocabulary they have and low of motivation to write. Many students are still lazy in writing because writing is considered a boring activity.

Teaching writing aims to improve students' ability to function effectively in such a written context. Writing is an educational content that is evident when there are errors in the use or spelling in writing that can change the meaning of the writing itself. If learners have mastered these skills, they will be able to write so that not only they can read what they have written, but other speakers of that language can read and understand it. Basically, from writing students are motivated to focus on using accurate language and because they think when they write. Harmer (2004) states that it may well provoke language developments as they resolve problems which the writer puts their minds. Zamel (1982) argues that writing is a process through which meaning is created. Raymond (1980) states that writing is a way of remembering and a way of thinking well. It means that writing is not just a communication tool but also to develop knowledge more clear, specific and detail.

However, Blanchard and Root (1998, cited in Parmawati, 2016) state that learning to write in a new language is not always easy. Therefore, the government handles this problem is by applying Curriculum 2013 in several schools. The 2013 curriculum aims to encourage students, 
ask questions, reason, and communicate (now) about what they get, or they know after receiving learning material. This is the setting of learning and enhancement of curriculum 2013 which emphasized natural, social, artistic and cultural phenomena. From the provisions of the curriculum 2013 teaching English learning is expected to be able to learners who are productive, creative, innovative, and effective.

Types of texts in Indonesia namely narrative text, descriptive text, recount text, report text and procedure text. In the teaching-learning process, the teacher needs learning models that are innovative and fits the 2013 curriculum. In this study, researchers used Snowball Throwing and Discovery learning to improve students' writing skill through narrative text. Narrative text is one genre that is taught for eleventh-grade students at senior high school in the last semester. Anderson (2003) explains that a narrative text is a text that tells a story and, in doing so, entertains the audience. Departemen Pendidikan defines Narrative text is imagination or a complicated event which directs to a crisis that finds a solution at last. Browning (1988) state narrative text is a continuous account of an event or a series of events. Based on that definition, it was concluded that text narrative is a story of imagination that has a series of interconnected events with the aim of entertaining the reader. Discovery learning can also help students become more critical that fits with the 2013 curriculum.

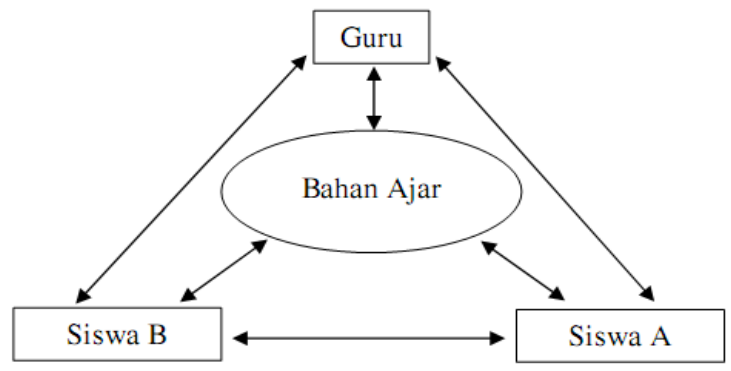

Figure 1. Learning activity in Guided Discovery Learning

Discovery learning is the learning approach of the curriculum 2013. Holesinska (2006) stated that discovery learning strategy is the most practical and encouraging example of active learning strategy in which the students have to work out rules and find the text concept by themselves. Similarly, Thorsett (2002) defined discovery learning as a learning situation in which the principal content of what is to be learned is not given, but must be independently discovered by the learner, making the student becomes an active participant in his learning. Refers to the definitions by experts above, it means that discovery learning relies more on student creativity in processing information from the text or learning process. Discovery learning is a method to improve the way of the active students in learning by discovering and investigating themselves, so the result that will get is permanent and memorable in their mind, it is unforgettable to students.

According to Kementrian Pendidikan dan Kebudayaan (2013), the stages of implementation on discovery learning consist of stimulation, problem statement, data collection, data processing, verification, and generalization. Here is the implementation of discovery learning in teaching students' reading comprehension using narrative text, there are:

1. Stimulation

The teacher explains the stages of discovery learning strategy faced by students during reading activities. 


\section{Problem Statement}

This stage requires students to prepare some questions about information showing by media delivered by the teacher.

3. Data Collection

The students collect as many information and structure about the narrative text.

4. Data Processing

The students in groups identify and process the information obtained from the data collection stage.

5. Verification

The students together with the teacher will start to process the text given at the beginning of the learning process and the students also try to identify the goals.

\section{Generalization}

In these final stages, the students will make the conclusion of the text and the information that they got from all of the previous activities. After making the conclusion, each of the group will present it in front of the class.

Based on the problems in writing skill, the researchers wanted to give the second solution to teach English in writing skill. That is by using the Snowball Throwing method. According to Darusmin, Delfi, and Masyhur (2012) as cited in Apsari (2019), snowball throwing as one modification of an interesting game that is mutually throwing snowballs which contains questions to fellow friends which focuses on the ability to formulate question.

The Snowball Throwing method is a way to present the material in a lesson where students formed a heterogeneous groups then each group is elected chairman of the group to get the task of the teacher and each student to create shaped like a football question (question paper) and then thrown to the other student each student to answer the question of balls obtained (Suprijono, 2009).

We can conclude that team teaching techniques can change the learning atmosphere to be more interesting and can be better also can affect cooperation between students. The cooperative learning models that focus on group work using discussion in which every group asks questions to another so that the group will work cooperatively to solve the problem. In addition, this game will be more interactive if the students enjoy the learning process.

According to Suprijono (2009), There are steps of implements Snowball Throwing Game, they are as follows:

1. Teacher deliver the material that will be learned.

2. Teacher make groups and call the chairman of each group to give an explanation about the material being taught to their students/members.

3. The group heads back to each group and explain any material submitted by the teacher to his friends.

4. Each student is given a sheet of paper, to write down one question concerning any matter which has been described by the group leader.

5. The paper containing these statements or questions was made into a ball and tossed one student to another student for about 15 minutes. 
6. Then, each student has one ball or one question and give the opportunity for the students to answer questions that are written in a ball-shaped paper in turn.

7. Evaluation, this step the teacher discusses the result of the student's answer. Then, give an evaluation of the correct answer.

8. Closing, this step the teacher completes the meeting with prayer.

It means that the activity of throwing a ball will make a group have spirit and be active because this activity makes the students not only to thinking, writing, and talking but they also do a physical activity that is rolled paper and throw it to the other students. Thus, each member of the group will be preparing for their turn to answer a question or guess a statement from a friend that contained in ball paper.

\section{METHOD}

This study uses quasi-experimental because it consists of two independent variables by comparing two methods namely discovery Learning and Snowball method. The goals are to find out which method is better in improving the ability to write high school students through narrative text. The quasi-experimental design is intended to identify comparative groups as closely as possible through three stages, namely the pre-test, which aims to determine the students' initial abilities before treatment, then given treatment with two different variables, and finally the post-test was conducted to find out the progress of students after being given treatment, whether there was an improvement or not. Therefore care can be said, treatment has caused differences in results between the control class and the experimental class. According to Cohen (2007) in Rukmini and Wachyu (2015)factorial design is used or research that has two or more independent variables that work on the dependent variable.

In general, this research is intended to analyze the application of the Snowball approach and discovery learning to the ability to write narrative texts to students of SMK LPPM 4 RI Padalarang with a sample of 60 students in class XI, namely 30 students from class X RPL 1 as a control class with discovery learning approach and class XI RPL 2 as a class experiment with snowball approach.

\section{RESULTS AND DISCUSSION}

\section{Results}

\section{Analysis of Data Pre-test}

The pre-test was conducted at the beginning of learning to measure students' initial ability to write narrative texts.

\section{a. Data Normality Test}

When analyzing the pre-test data the first test is the normality test. The goal is to know whether or not normal data is distributed. In this Normality test testing using Kolmogorov-Smirnov, with the hypothesis as follows:

if $\operatorname{sig} \geq 0.5$, it is estimated that normal pre-test data is distributed.

if sig $<0.5$, it is estimated that the pre-test data is not normally distributed.

From the results of testing from SPSS 22, the results obtained are as follows. 
Table 1. Test results of data pre-test from two group

\section{Tests of Normality}

\begin{tabular}{|lll|l|l|l|l|l|l} 
& \multicolumn{3}{c}{ Kolmogorov-Smirnov } & \multicolumn{3}{c}{ Shapiro-Wilk } \\
& Class & Statistic & Df & Sig. & Statistic & df & Sig. \\
\hline Pre_test_writin & Control &, 168 & 30 &, 030 &, 894 & 30 &, 006 \\
\cline { 2 - 10 } g & experiment &, 151 & 30 &, 079 &, 928 & 30 &, 043 \\
\hline
\end{tabular}

a. Lilliefors Significance Correction

From the normality test, it can be known that the Sig. the control class pre-test value is 0,030 and Sig. The pre-test value of the experimental class is Sig. 0.079. Because of the significance of the value of the control class $<0.05$, it means that one class has pre-test data not normally distributed.

\section{b. Mann-Whitney Test}

Because the pretest data that is owned by the control class is not normally distributed, the next step is to do the Mann-Whitney test, with the following hypothesis:

$\mathrm{H}_{0}$ : There are not initial differences in students' text narrative writing skills

$\mathrm{H}_{\mathrm{a}}$ : There are initial differences in students' text narrative writing skills.

There are the following criteria:

If Sig.> 0,05 then $\mathrm{H}_{0}$ is accepted

If Sig. $\leq 0,05$ the $\mathrm{H}_{\mathrm{a}}$ is accepted

Table 2. Mann-Whitney test results in Pre-test data Two groups

\section{Test Statistics}

\begin{tabular}{lr} 
& Pre-test writing \\
\hline Mann-Whitney U & 420,000 \\
\hline Wilcoxon W & 885,000 \\
\hline Z &,- 447 \\
\hline Asymp. Sig. (2-tailed) &, 655 \\
\hline
\end{tabular}

a. Grouping Variable: class

From the Mann-Whitney test results obtained that Asymp. Sig (2-tailed) is 0.655 because H0 is accepted and $\mathrm{Ha}$ is rejected. From the results of these tests, this means that there is no difference in the initial writing skills of students.

\section{Post-test data analysis}

The next step is to analyze the post-test data with the same steps as the pre-test, namely the post-test data normality test. 


\section{a. Data Normality Test}

When analyzing the post-test data the first test is the normality test. The goal is to know whether or not normal data is distributed. In this Normality test testing using Kolmogorov-Smirnov, with the hypothesis as follows:

if $\operatorname{sig} \geq 0.5$, it is estimated that normal pre-test data is distributed.

if sig $<0.5$, it is estimated that the pre-test data is not normally distributed.

Table 3. Test Normality results of data post-test from two group

\section{Tests of Normality}

\begin{tabular}{|c|c|c|c|c|c|c|c|}
\hline & \multirow[b]{2}{*}{ Class } & \multicolumn{3}{|c|}{ Kolmogorov-Smirnov ${ }^{a}$} & \multicolumn{3}{|c|}{ Shapiro-Wilk } \\
\hline & & Statistic & df & Sig. & Statistic & df & Sig. \\
\hline \multirow[t]{2}{*}{ Post_test_Writing } & Control &, 169 & 30 & ,029 & ,906 & 30 &, 012 \\
\hline & $\begin{array}{l}\text { experimen } \\
\mathrm{t}\end{array}$ &, 164 & 30 & ,038 & ,913 & 30 &, 017 \\
\hline
\end{tabular}

a. Lilliefors Significance Correction

From the normality test, it can be known that the Sig. the control class post-test value is 0,029 and Sig. the value of the experimental class post-test is Sig. 0.038. Because of the significance of the value of the control class and experiment class $<0.05$, it can be concluded that both classes have post-test data not normally distributed.

\section{b. Mann-Whitney Test}

Because the post-test normality test value in the control and experimental classes are not normally distributed, then the next step is the Mann-Whitney test, with the following hypothesis:

$\mathrm{H}_{0}$ : The achievement of students' writing ability using the Snowball method is less than or equal to the discovery learning approach significantly.

$\mathrm{H}_{\mathrm{a}}$ : The achievement of writing skills of students using the snowball approach is better than discovery learning.

There are the following criteria:

If Sig.> 0,05 then $\mathrm{H}_{0}$ is accepted If Sig. $\leq 0,05$ the $\mathrm{H}_{\mathrm{a}}$ is accepted

Table 4. Mann-Whitney test results in Post-test data Two groups

\section{Test Statistics}

\begin{tabular}{lr} 
& \multicolumn{1}{c}{ Post-test Writing } \\
\hline Mann-Whitney U & 113,000 \\
\hline Wilcoxon W & 578,000 \\
\hline Z & $-5,034$ \\
\hline Asymp. Sig. (2-tailed) &, 000 \\
\hline
\end{tabular}


a. Grouping Variable: Kelas

Based on the Mann-Whitney test results obtained that Asymp. Sig (2-tailed) is 0.000 it means $\mathrm{Ha}$ is accepted and $\mathrm{H} 0$ is rejected. From the results of these tests, it can be concluded that the achievement of students' writing skills using the snowball approach is better than discovery learning.

\section{Analysis Gain Score}

The next step is to find the difference in the pre-test and post-test values through the Gain test.

\section{a. Data Normality test}

When analyzing the Gain data the first test is the normality test. The goal is to know whether or not normal data is distributed. In this Normality test testing using Kolmogorov-Smirnov, with the hypothesis as follows:

if $\operatorname{sig} \geq 0.5$, it is estimated that normal Gain data is distributed.

if $\operatorname{sig}<0.5$, it is estimated that the Gain data is not normally distributed.

Table 5. Test Normality results of data Gain from two group

\begin{tabular}{|c|c|c|c|c|c|c|c|}
\hline \multicolumn{8}{|c|}{ Tests of Normality } \\
\hline & & \multicolumn{3}{|c|}{ Kolmogorov-Smirnov ${ }^{\mathrm{a}}$} & \multicolumn{3}{|c|}{ Shapiro-Wilk } \\
\hline & Class & Statistic & $\mathrm{df}$ & Sig. & Statistic & $\mathrm{df}$ & Sig. \\
\hline \multirow[t]{2}{*}{ Gain } & Control &, 188 & 30 &, 008 &, 846 & 30 &, 001 \\
\hline & experiment &, 104 & 30 &, $200^{*}$ & ,973 & 30 & ,610 \\
\hline
\end{tabular}

From the normality test, it can be seen that the Sig. the control class Gain value is 0,008 and Sig. the value of the experimental class Gain is Sig. 0.200. Because of the significance of the value of the control class $<0.05$, it can be concluded that one class of Gain data is not normally distributed.

\section{a. Mann-Whitney Test}

Because the Gain data that is owned by the control class is not normally distributed, the next step is to do the Mann-Whitney test, with the following hypothesis:

$\mathrm{H}_{0}$ : There is no change in the value of students' writing skills.

$\mathrm{H}_{\mathrm{a}}$ : There is a change in the value of students' writing skills.

There are the following criteria:

If Sig.> 0,05 then $\mathrm{H}_{0}$ is accepted If Sig. $\leq 0,05$ the $\mathrm{H}_{\mathrm{a}}$ is accepted 
Table 6. Mann-Whitney test results in Gain data Two groups

Test Statistics

\begin{tabular}{lr} 
& \multicolumn{1}{c}{ Gain } \\
\hline Mann-Whitney U & 6,500 \\
\hline Wilcoxon W & 471,500 \\
\hline Z & $-6,561$ \\
\hline Asymp. Sig. (2-tailed) &, 000 \\
\hline
\end{tabular}

a. Grouping Variable: Kelas

Based on the Mann-Whitney test results obtained that Asymp. Sig (2-tailed) is 0.000 it means $\mathrm{Ha}$ is accepted and $\mathrm{H} 0$ is rejected. From the results of these tests, it can be concluded that the change value of students' writing skills using the snowball approach is better than discovery learning.

\section{Discussion}

In each control and experimental class before being given treatment, students were first measured the ability to write a text narrative by being given a pre-test. The results of the pretest showed that there was no initial difference in the ability to write a narrative text of students. Then the next step students are given treatment with the provisions of the control class using discovery learning and experimental classes using the Snowball method. Then the next stage students are given the final test (post-test) to measure students' writing ability after being given treatment both control and experimental classes. The results of the post-test of both classes namely control and experimental showed that the improvement or achievement of students ability to write narrative texts using the Snowball method is effective and better than using discovery learning. after carrying out these steps, the gain test is carried out to determine changes in the writing value of students before being given treatment and after being given treatment. From the results obtained from the test results of the gain of 60 students showed a significant change in value with the snowball method compared to discovery learning.

\section{CONCLUSION}

From the results of this study, the researchers concluded that the ability to write students using the Snowball method is better than using discovery learning. In addition, there is a change in the value of writing narrative texts of students using the snowball method rather than discovery learning.

\section{ACKNOWLEDGMENTS}

The highest gratitude to Allah SWT for opportunity and blessing us, so we can complete this article. We thank the beloved campus IKIP SILIWANGI Bandung as our institution.

\section{REFERENCES}

Anderson, M, and A. (2003). Text Types in English 1-2. Australia: Macmillan Education Australia.

Nurmalasari, M., \& Apsari, Y. (2019). Improving Students' Participation in Speaking English Using Snowball Throwing Technique. PROJECT (Professional Journal of English 
Education), 2(2), 14-20.

Browning, G, B, A. (1988). Fiction for Composition. USA: Scott, Foresman and Company.

Harmer, J. (2004). How to Teach. England: Pearson Education.

Holesinska, A. (2006). Teaching English as a Foreign Language to Students with Learning Difficulties. Masaryk: Mararyk University Press.

Kementrian Pendidikan dan Kebudayaan. (2013). Model Pembelajaran Penemuan (Discovery Learning). Jakarta: Kementrian Pendidikan Nasional.

Mundriyah, M., \& Parmawati, A. (2016). Using Think-Pair-Share (Tps) To Improve

Students'writing Creativity (A Classroom Action Research In The Second Semester

Students Of Stkip Siliwangi Bandung). P2m Stkip Siliwangi, 3(2), 84-91.

Raymond, J, C. (1980). Writing is an Unnatural Act. New York: Harper Publisher.

Rukmini and Wachyu, M. I. (2015). The Effectiveness of Project Based Learning and

Problem Based Learning for Teaching Biography Text Writing to Highly and Lowly

Motivated Students. Language Circle.

Suprijono, A. (2009). Cooperative Learning. Teori dan Implikasi PALKEM. Yogyakarta:

Pustaka Belajar.

Thorsett, P. (2002). Discovery Learning Theory a Primer for Discussion. EPRS 8500.

Zamel, V. (1982). The Process of Discovery Meaning. TESOL Quaterly. 